\title{
Plight of the unsung ecosystems
}

Although science aims to eliminate bias, it can never be fully objective. Wildlife and conservation research are far from being exempt from this tendency. For example, flagship species often take precedence over species that may be in more dire need of assistance. Factors such as species' role within ecosystems, their habitat range, degree of endangerment and taxonomic uniqueness do not stand much chance when competing against "charismatic" species receiving adulation from the public and funding agencies (Troudet et al. 2017, Tensen 2018). This is not to say that these emblematic species should not be recipients of conservation attention. However, considering the all-too limited funding pot available to conservation projects, taking a system perspective rather than a species perspective, by considering flagship species as part of a larger whole-i.e., at the ecosystem scale-is crucial, although unfortunately not often achieved (Ripple et al. 2016, Donaldson et al. 2017).

Currently, and in part due to this taxonomic bias, entire ecosystems are subject to wide discrepancies in research and funding attention, unrelated to their biodiversity richness or the ecosystem services they provide (Di Marco et al. 2017). Wetlands are a case in point. Covering an estimated $6 \%$ of terrestrial surface and occurring around the globe, these ecosystems are home to high concentrations of biodiversity and play a vital role for communities and society as a whole (Reis et al. 2017). Wetlands provide a wide variety of ecosystem services, falling under the umbrellas of regulating services (air and water quality, erosion, natural hazard mitigation), provisioning services (fish, crops, biomass), cultural services (recreation, tourism), and supporting services (formation of soils) (Ramsar Convention on Wetlands 2018). However, a large proportion of these ecosystems are under threat due to anthropogenic activities (Dohong et al. 2017, Ricaurte et al. 2017, Sievers et al. 2018). The Ramsar Convention's Global Wetland Outlook (2018) report found that natural coastal and inland wetlands were declining at three times the rate of forests globally, with 35\% having been lost since 1970.

In Madagascar, wetlands provide vital nutritional resources to its inhabitants, being the cultivation ground for rice, and supplying fish, raw materials such as reeds used for housing, crafts and tools, and medicinal plants to a large proportion of the population (Neugarten et al. 2016, Rakotoarivelo et al. 2020). This intense use has however put these ecosystems under enormous pressure, and has led to their widespread degradation. Pollution, over-extraction, and the introduction of alien species are just a few of the drivers behind their deterioration (Jones et al. 2016, Máiz-Tomé et al. 2018, Scales and Friess 2019).

Despite their growing vulnerability and biological and societal importance, wetlands have received little attention from research compared to other ecosystems. Looking at freshwater systems across Africa (Madagascar was not included), Darwall et al. (2011) found that a strong discrepancy between conservation attention and the threat and richness of species, as well as freshwater systems being underrepresented within protected area networks. In Madagascar, most conservation work over the past decades has focused on forest protection, with far less resources having gone towards wetlands (Bamford et al. 2017). The country's wetlands have been rapidly shrinking, for example in the highlands that have seen the disappearance of $60 \%$ of wetlands compared to 20\% of forests since 1960 (Kull 2012, Bamford et al. 2017). In a study looking at the dynamics of Madagascar's mangroves, Jones et al. (2016) found an overall net loss of 21\% between 1990 and 2010. Searching Web of Science illustrates this research imbalance: while the keywords (Forest AND Madagascar) returns 2228 hits, searching for ((Wetland OR Lagoon OR Coral reef OR Delta OR Marsh* OR Mangrove OR Swamp OR Bog) AND Madagascar) returns a meagre 438 results (25 October 2019). One explanation for this large discrepancy could be the taxonomic bias discussed above. Arguably, Madagascar's most well-known flagship species are lemurs (Thalmann 2006), which almost exclusively inhabit forests, and have helped attract conservation resources and the establishment of protected areas (Scales 2014, Waeber et al. 2016). An exception is the Alaotra gentle lemur (Hapalemur alaotrensis), the only lemur living exclusively in marshes and endemic to the disappearing wetlands of Lake Alaotra (Rendigs et al. 2015). This species has helped attract much research and conservation attention for the socio-ecological system of the Alaotra region as a whole (Naudin et al. 2015, Wallace et al. 2016, Waeber et al. 2019). Despite these efforts, the future of the species and the ecosystem they are part of looks bleak (Reibelt et al. 2019). Yet, these wetlands are in actual fact the lucky ones, having been able to attract funding and research interest. The difficulties in curbing the degradation trend they are facing only makes the safeguard of wetlands not home to such flagship species seem more daunting.

Yet, considering the high stakes of wetland conservation and the fast pace of change they are experiencing, research surrounding these ecosystems is ever more crucial. The articles in this special issue show us that many researchers are undertaking this challenging task. The studies cover a wide variety of Madagascar's wetlands, and take both ecological and social approaches, illustrating their diversity and significance for the country as a whole. I hope that this special issue will help shine a brighter light on these vital ecosystems, and contribute to their further understanding and protection.

\section{Natasha Stoudmann}

Forest Management and Development

Swiss Federal Institute of Technology (ETH) Zurich

Switzerland

n.stoudmann@hotmail.com 


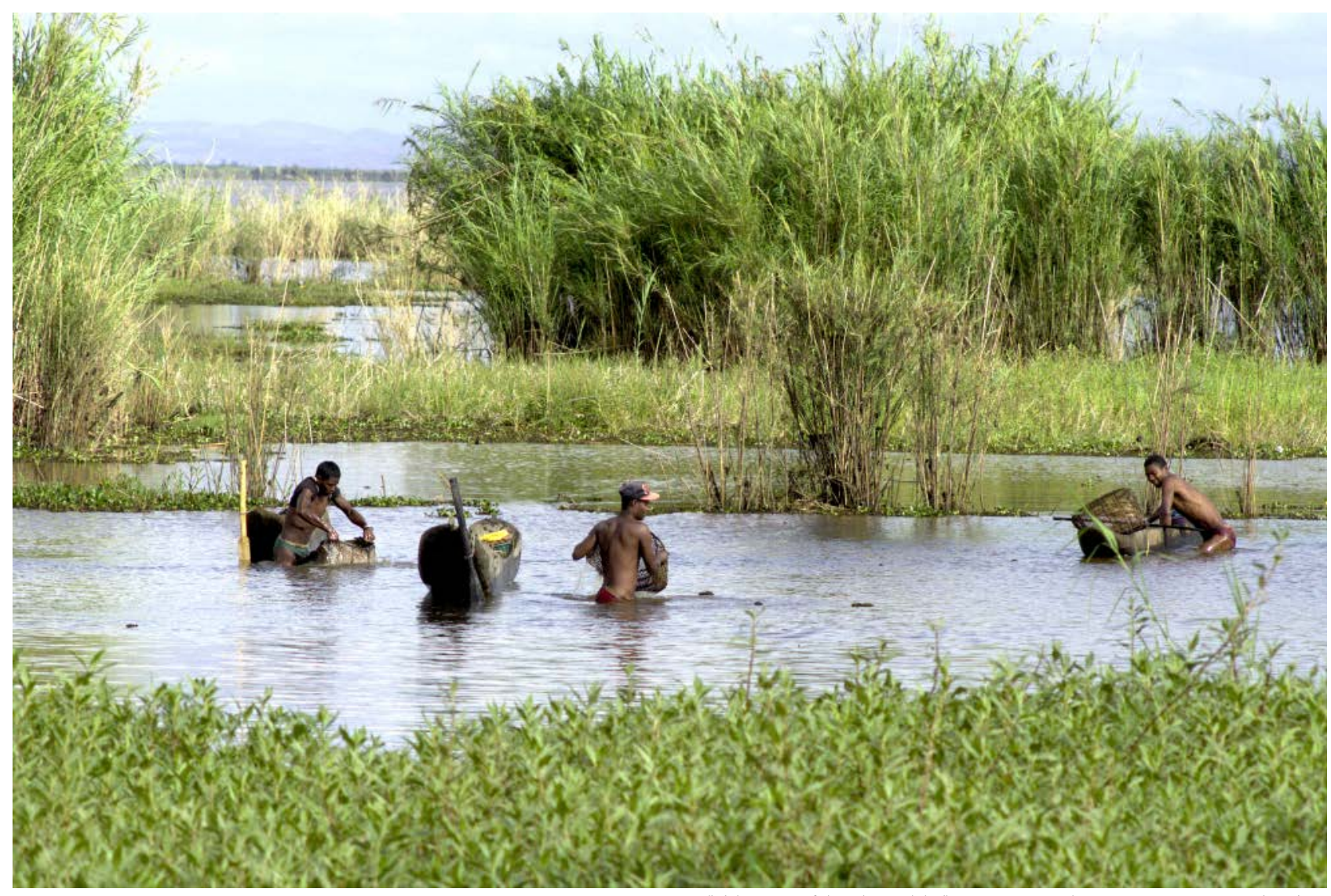

"Fishermen of the Alaotra lake" @ 2016, Arnaud De Grave / Agence Le Pictorium

\section{REFERENCES}

Bamford, A. J., Razafindrajao, F., Young, R. P. and Hilton, G. M. 2017. Profound and pervasive degradation of Madagascar's freshwater wetlands and links with biodiversity. PLoS ONE 12, 8: e0182673. <https://doi.org/10.1371/journal.pone.0182673>

Darwall, W. R. T., Holland, R. A., Smith, K. G., Allen, D., Brooks, E. G. E., et al. 2011. Implications of bias in conservation research and investment for freshwater species. Conservation Letters 4, 6: 474-482. <https://doi.org/10.1111/j.1755-263X.2011.00202.x>

Dohong, A., Aziz, A. A. and Dargusch, P. 2017. A review of the drivers of tropical peatland degradation in South-East Asia. Land Use Policy 69: 349-360. <https://doi.org/10.1016/j.landusepol.2017.09.035>

Donaldson, M. R., Burnett, N. J., Braun, D. C., Suski, C. D., Hinch, S. G., et al. 2017. Taxonomic bias and international biodiversity conservation research. Facets 1, 1: pp. 105-113. <https://doi.org/10.1139/facets-2016-0011>

Jones, T. G., Glass, L., Gandhi, S., Ravaoarinorotsihoarana, L., Carro, A., et al. 2016 Madagascar's mangroves: Quantifying nation-wide and ecosystem specific dynamics, and detailed contemporary mapping of distinct ecosystems. Remote Sensing 8, 2: \#106. <https://doi.org/10.3390/rs8020106>

Kull, C. 2012. Air photo evidence of historical land cover change in the highlands: Wetlands and grasslands give way to crops and woodlots. Madagascar Conservation \& Development 7, 3: 144-153. <https://doi.org/10.4314/mcd.v7i3.7>

Máiz-Tomé, L., Sayer, C. and Darwall, W. R. T. (eds). 2018. The status and distribution of freshwater biodiversity in Madagascar and the Indian Ocean islands hotspot. IUCN, Gland, Switzerland. Available online <https://doi.org/10.2305/iucn.ch.2018.ra.1.en>

Di Marco, M., Chapman, S., Althor, G., Kearney, S., Besancon, C., et al. 2017. Changing trends and persisting biases in three decades of conservation science. Global Ecology and Conservation 10: 32-42. <https://doi.org/10.1016/j.gecco.2017.01.008>
Naudin, K., Bruelle, G., Salgado, P., Penot, E., Scopel, E., et al. 2015. Trade-offs around the use of biomass for livestock feed and soil cover in dairy farms in the Alaotra lake region of Madagascar. Agricultural Systems 134: 36-47. <https://doi.org/10.1016/j.agsy.2014.03.003>

Neugarten, R. A., Honzák, M., Carret, P., Koenig, K., Andriamaro, L., et al. 2016. Rapid assessment of ecosystem service co-benefits of biodiversity priority areas in Madagascar. PLOS ONE 11, 12: 1-25. <https://doi.org/10.1371/journal.pone.0168575>

Rakotoarivelo, N. H., Manjato, N. V., Andriamiarisoa, L. R., Bernard, R. and Andriambololonera, S. 2019. Useful plants in the Park Bandro and its surroundings, Lake Alaotra, Madagascar. Madagascar Conservation \& Development. <https://doi.org/10.4314/mcd.wetlands.4>

Ramsar Convention on Wetlands. 2018. Global Wetland Outlook: State of the World's Wetlands and their Services to People. Ramsar, Gland, Switzerland. Available online <https://www.global-wetland-outlook.ramsar.org/outlook>

Reibelt, L. M., Andrianandrasana, H. T., Ralainasolo F., Raveloarimalala, L. M., Lewis, R., et al. 2019. Lake Alaotra Gentle Lemur Hapalemur alaotrensis Rumpler 1975, Madagascar. In: Primates in peril: The world's 25 most endangered primates 2018-2020. Schwitzer, C. et al. (eds.), pp 9-11. IUCN SSC Primate Specialist Group (PSG), International Primatological Society (IPS), Global Wildlife Conservation (GWC), Bristol Zoological Society (BZS).

Reis, V., Hermoso, V., Hamilton, S. K., Ward, D., Fluet-Chouinard, E., et al. 2017. A global assessment of inland wetland conservation status. Bioscience 67,6 : 523-533. <https://doi.org/10.1093/biosci/bix045>

Rendigs, A., Reibelt, L. M., Ralainasolo, F. B., Ratsimbazafy, J. H., Waeber, P. O. 2015. Ten years into the marshes - Hapalemur alaotrensis conservation, one step forward and two steps back? Madagascar Conservation \& Development 10 1: 13-20. <https://doi.org/10.4314/mcd.v10i1.s3>

Ricaurte, L. F., Olaya-Rodríguez, M. H., Cepeda-Valencia, J., Lara, D., ArroyaveSuárez, J, et al. 2017. Future impacts of drivers of change on wetland ecosystem services in Colombia. Global Environmental Change 44: 158-169. <https://doi.org/10.1016/j.gloenvcha.2017.04.001> 
Ripple, W. J., Chapron, G., López-Bao, J. V., Durant, S. M., Macdonald, D. W., et al. 2016. Saving the World's terrestrial megafauna. BioScience 66, 10: 807-812. <https://doi.org/10.1093/biosci/biw092>

Scales, I. 2014. The future of conservation and development in Madagascar: Time for a new paradigm? Madagascar Conservation \& Development 9, 1: 5-12. <https://doi.org/10.4314/mcd.v9i1.2>

Scales, I. R. and Friess, D. A. 2019. Patterns of mangrove forest disturbance and biomass removal due to small-scale harvesting in southwestern Madagascar. Wetlands Ecology and Management 27, 5: 609-625. <https://doi.org/10.1007/s11273-019-09680-5>

Sievers, M., Hale, R., Parris, K. M., Swearer, S. E. 2018. Impacts of human-induced environmental change in wetlands on aquatic animals. Biological Reviews 93, 1: 529-554. <https://doi.org/10.1111/brv.12358>

Tensen, L. 2018. Biases in wildlife and conservation research, using felids and canids as a case study. Global Ecology and Conservation 15: e00423. <https://doi.org/10.1016/j.gecco.2018.e00423>

Thalmann, U. 2006. Lemurs - Ambassadors for Madagascar. Madagascar Conservation \& Development 1, 1: 4-8. <https://doi.org/10.4314/mcd.v1i1.44043>

Troudet, J., Grandcolas, P., Blin, A., Vignes-Lebbe, R. and Legendre, F. 2017. Taxonomic bias in biodiversity data and societal preferences. Scientific Reports 7. 1: 1-14. <https://doi.org/10.1038/s41598-017-09084-6>

Waeber, P. O., Wilmé, L., Mercier, J.-R., Camara, C. and Lowry, P. P. 2016. How effective have thirty years of internationally driven conservation and development efforts been in Madagascar? PLOS ONE 11, 8: 1-13. <https://doi.org/10.1371/journal.pone.0161115>

Waeber, P. O., De Grave, A., Wilmé, L. and Garcia, C. 2017. Play, learn, explore: grasping complexity through gaming and photography. Madagascar Conservation \& Development. <https://doi.org/10.4314/mcd.wetlands.1>

Wallace, A. P. C., Jones, J. P. G., Milner-Gulland, E. J., Wallace, G. E., Young, R. and Nicholson, E. 2016. Drivers of the distribution of fisher effort at Lake Alaotra, Madagascar. Human Ecology 44, 1: 105-117.

<https://doi.org/10.1007/s10745-016-9805-1> 